\title{
PENERAPAN PRINSIP GOOD CORPORATE GOVERNANCE PADA PERUSAHAAN PENJAMINAN (STUDI KASUS PT JAMKRINDO)
}

\author{
MUHAMMAD MUCHLAS ROWI \\ muchlas.rowi@ibm.ac.id \\ Program Studi Manajemen \\ Institut Bisnis Muhammadiyah Bekasi
}

\begin{abstract}
The application of the principles of Good Corporate Governance was suppressed after economic crises in various countries in the 1990s. When observing the major financial scandals that were exposed, the public began to question the performance of the big companies involved in this scandal which went against the principles of Good Corporate Governance regarding accountability, equity, integrity, transparancy and responsibility. PT Jamkrindo is a state-owned company engaged in underwriting with program and nonprogram products. PT Jamkrindo is here to participate in elevating MSME-K actors to become more independent, develop and advance. PT Jamkrindo must implement good governance or Good Corporate Governance. This is important because so far MSMEs are not considered to need good corporate governance. Even though MSMEs contribute greatly to the Indonesian economy.
\end{abstract}

Keyword: Good Corporate Governance, Jamkrindo, UMKM

\section{A. PENDAHULUAN}

Perum Jamkrindo merupakan badan usaha milik negara yang bergerak di bidang penjaminan dengan produk program dan non program. (Santo, 2019) Sebagai contoh produk untuk mendukung program pemerintah adalah penjaminan kredit usaha rakyat atau KUR, penjaminan kredit pemilikan rumah atau KPR sejahtera dengan skema fasilitas likuiditas pembiayaan perumahan atau FLPP serta penjaminan sistem resi gudang. Adapun produk nonprogram adalah penjaminan kredit. Adapun produk non-program adalah penjaminan kredit/pembiayaan umum, penjaminan kredit/pembiayaan mikro, penjaminan kredit/pembiayaan konstruksi dan pengadaan barang/jasa, penjaminan kredit/pembiayaan multiguna, penjaminan distribusi barang, penjaminan bank garansi/kontra garansi, surety bond, penjaminan kredit BPR/BPRS, custom bond, penjaminan keagenan kargo, penjaminan invoice financing, penjaminan skema subsidi resi gudang, dan penjaminan fintech.

Dalam hal penerapan tata kelola perusahaan yang baik atau Good Corporate Governance, Perum Jamkrindo meraih juga predikat dengan kualifikasi sangat baik dan berdasarkan sertifikasi PEFINDO (Credit Rating Agency) berperingkat AA Plus (Double A Plus, Stable Outlook). (Satriani, 2016) Good Corporate Governance yang diterapkan di PT Jamkrindo menjadi sangat penting, karena dianggap mampu menjamin kualitas dan keberlangsungan perusahaan UMKM. Faktanya, selama ini keberlangsungan bisnis UMKM di Indonesia kebanyakan hanya bertahan 
selama 10 tahun. Ini jauh lebih singkat jika dibandingkan dengan keberadaan UMKM di negara-negara maju, bisa bertahan lebih lama. Belum lagi jika menilik kembali pada Peringkat Good Corporate Governance Indonesia yang ternyata masih rendah di banding Malaysia, Singapura dan Filipina.

\section{Penerapan Good Corporate} Governance sangat penting, mengingat investasi sulit masuk ke Indonesia, salah satu penyebabnya adalah UMKM yang memiliki porsi paling besar dalam perekonomian Indonesia belum menerapkan Good Corporate Governance secara maksimal. Fakta lain, menurut penilaian Indonesian Institute for Corporate Directorship (IICD) terhadap 200 emiten yang ditelitinya, bahwa praktik tata kelola perusahaan-perusahaan terbuka di Indonesia masih sekadar memenuhi standar minimum yang disyaratkan oleh Undang-Undang dan regulasi, sehingga perkembangannya dalam kondisi stagnan.

\begin{tabular}{|c|c|c|}
\hline $\begin{array}{c}\text { Hal } \\
\text { menunjukkan }\end{array}$ & $\begin{array}{l}\text { tersebut } \\
\text { betapa }\end{array}$ & $\begin{array}{l}\text { kemudian } \\
\text { pentingnya }\end{array}$ \\
\hline $\begin{array}{l}\text { penegakan } \\
\text { perubahan }\end{array}$ & $\begin{array}{cc}\text { regulasi } & \text { yang } \\
\text { budaya } & \text { Good }\end{array}$ & $\begin{array}{l}\text { kuat dan } \\
\text { Corporate }\end{array}$ \\
\hline
\end{tabular}
Agar perusahaan ataupun UMKM yang hendak naik kelas dapat menciptakan sebuah keseimbangan, serta fungsi pengawasan berjalan dengan baik, antara kepentingan pemilik usaha, dengan pengguna produk atau jasa usaha serta kepentingan-kepentingan stakeholder lainnya dapat terjembatani secara seimbang juga.

Di era disrupsi seperti sekarang ini, penerapan Good Corporate Governance menjadi faktor penentu keberhasilan dunia usaha. Ternyata, masalah utama UMKM di Indonesia terletak pada akuntabilitas dan transparansi yang masih rendah sehingga ke depannya harus terus ditingkatkan. Jika UMKM dapat mengimplementasikan prinsip-prinsip tata kelola Good Corporate Governance dengan sangat baik, maka tentunya persoalan yang selama ini dihadapi yaitu akses permodalan dapat teratasi. Apalagi dalam konteks ini, lembaga penjaminan terutama Perum Jamkrindo seperti diamanatkan dalam PP 35 tahun 2018 telah memperluas spektrum usahanya sesuai dengan perkembangan teknologi dan dunia industri terkini.

Usaha-usaha rintisan (startup business) yang memenuhi kriteria UMKM dan bergerak di bidang financial technology (FinTech), ritel, teknologi, jasa, dan bidang lainnya bisa mendapatkan penjaminan pembiayaan dari Jamkrindo. Melalui PP 35 ini Jamkrindo bahkan bisa melaksanakan penjaminan pembiayaan untuk kegiatan usaha yang dijalankan oleh non-UMKM, tetapi dalam koridor sinergi BUMN. Dengan upaya-upaya seperti ini, maka UMKM bukan tidak mungkin mampu menyelamatkan Indonesia dari jebakan kelas menengah saja, tapi juga membuat Indonesia bisa melakukan lompatan kemajuan bagi ekonomi.

\section{B. METODE PENELITIAN}

Metode penelitian yang digunakan dalam penelitian ini adalah metode penelitian hukum yuridis normatif dan yuridis empiris. Sedangkan Teknik pengumpulan data dalam penelitian ini menggunakan metode pengumpulan data deskriptif.

Dalam penyusunan penelitian ini, peneliti menggunakan bahan-bahan yang diperoleh dari tinjauan kepustakaan yang bersumber dari buku-buku dan literatur lain. Data yang diperoleh peneliti akan dianalisa secara kualitatif dan disajikan secara deskriptif, yaitu menganalisis data yang diperoleh 
berdasarkan aturan hukumnya serta untuk menentukan ada tidaknya hubungan antara suatu gejala dengan gejala lain dalam masyarakat.

Dalam penulisan skripsi ini, peneliti memilih 2 (dua) tempat penelitian, yaitu:

a) Perpustakaan Sekolah Tinggi Ilmu Hukum (STIH) Dharma Andigha Bogor, mencari sumber-sumber literatur terkait pembahasan skripsi ini.

b) Kantor Pusat PT Jamkrindo, untuk menghimpun dokumen berupa laporan terkait pelaksanaan GCG di perusahaan penjaminan tersebut.

c) Jurnal, artikel, maupun data melalui situs-situs yang dianggap anggap relevan dari internet.

\section{HASIL PEMBAHASAN}

\section{Implementasi Prinsip-prinsip Good Corporate Governance di PT Jamkrindo}

Dalam rangka menciptakan nilai tambah yang berkelanjutan bagi perusahan, PT Jamkrindo berkomitmen penuh menerapkan prinsip Good Corporate Governance (GCG) sebagai budaya dan landasan perusahaan. Hal itu dilakukan demi kepentingan para pemegang saham, masyarakat secara luas, dan berbagai pemangku kepentingan lainnya seperti pegawai, konsumen, regulator, mitra kerja, dan lain sebagainya, baik dalam jangka pendek maupun jangka panjang. Komitmen Jamkrindo diwujudkan dengan menyusun Pedoman Tata Kelola yang diterapkan secara konsisten sehingga semua nilai yang dimiliki oleh pihak-pihak yang berkepentingan atas perusahaan dapat digunakan secara optimal dan menghasilkan pola hubungan ekonomis yang saling menguntungkan. Pedoman Tata Kelola Perusahaan atau Code of Corporate
Governance (COCG) merupakan kristalisasi dari berbagai sumber GCG, antara lain: peraturan perundangundangan yang berlaku, nilai-nilai budaya yang diterapkan, visi dan misi serta praktik-praktik terbaik (best practices) GCG.

Salah satu wujud komitmen terhadap implementasi prinsip-prinsip GCG, PT Jamkrindo telah mengadopsi standar pedoman GCG Indonesia yang diterbitkan oleh Komite Nasional Kebijakan Governance (KNKG) tahun 2006, serta mengacu pada kriteria dan metodologi yang ditetapkan oleh Kantor Kementerian Negara Badan Usaha Milik Negara No. SK-16/S.MBU/2012 tanggal 6 Juni 2012, kemudian juga menerapkan aturan aturan GCG berdasarkan pada penilaian ASEAN Corporate Governance Scorecard (ACGS) yang diterbitkan oleh ASEAN Capital Market Forum.

Penerapan prinsip-prinsip GCG bukan hanya untuk memenuhi peraturan perundang-undangan. PT. Jamkrindo memiliki komitmen yang kuat, bahwa penerapan GCG harus berlandaskan pada standar etika tertinggi yang menjadi salah satu fondasi bagi pertumbuhan usaha Perusahaan yang berkelanjutan. Untuk mencapai hal tersebut, Perusahaan memedomani prinsip tata kelola perusahaan yang baik. Dalam menerapkan GCG, manajemen dan karyawan PT Jamkrindo berpedoman standar pedoman GCG Indonesia yang diterbitkan oleh Komite Nasional Kebijakan Governance (KNKG) tahun 2006, juga peraturan Menteri BUMN nomor: PER 01/MBU/2011, serta Peraturan Otoritas Jasa Keuangan Nomor: 03/POJK.05/2017 Tentang Tata Kelola Perusahaan yang baik bagi Lembaga Penjamin. yakni pada 5 (lima) prinsip dasar yaitu: transparansi, akuntabilitas, pertanggung jawaban, kemandirian, dan 
kewajaran, sebagaimana telah dirilis dalam Pedoman Tata Kelola Perusahaan.

\section{Transparansi (Transparency)}

Prinsip transparansi yaitu keterbukaan dalam melaksanakan proses pengambilan keputusan dan keterbukaan dalam mengemukakan informasi material dan relevan mengenai Perusahaan. Perusahaan akan mematuhi peraturan perundang-undangan yang mengatur masalah keterbukaan informasi yang berlaku bagi Perusahaan. Transparansi juga mencakup hal-hal yang relevan dengan informasi yang dibutuhkan oleh publik berkaitan dengan produk dan aktivitas operasional Perusahaan yang secara potensial dapat mempengaruhi perilaku pemangku kepentingan. Dalam implementasinya, PT. Jamkrindo melaksanakan aktivitas keterbukaan informasi melalui pemenuhan kewajiban pelaporan kepada Pemegang Saham, dan melalui pelaporan keuangan dan melalui media komunikasi resmi.

\section{Akuntabilitas (Accountabillity)}

Prinsip akuntabilitas yaitu kejelasan fungsi, pelaksanaan dan pertanggungjawaban Organ Perusahaan sehingga pengelolaan Perusahaan terlaksana secara efektif. Akuntabilitas berkaitan dengan pelaksanaan tugas dan wewenang yang dimiliki seseorang atau satuan kerja dalam melaksanakan tanggung jawab yang dibebankan Perusahaan. Akuntabilitas ini meliputi penjelasan atas pelaksanaan tugas dan wewenang, pelaporan atas pelaksanaan tugas dan wewenang, serta pertanggungjawaban atas aktivitas dalam melaksanakan tugas dan wewenang tersebut. Pada implementasinya, PT Jamkrindo memiliki struktur tata kelola perusahaan yakni organ utama yang saling menunjang terciptanya pelaksanaan tugas yang transparan dan independen.
Perusahaan juga telah melengkapi pedoman-pedoman yang berfungsi untuk menjadi panduan penerapan tata kelola perusahaan.

\section{Pertanggungja waban (Responsibillity)}

Prinsip pertanggungjawaban yaitu kesesuaian di dalam pengelolaan Perusahaan terhadap peraturan perundang-undangan yang berlaku dan prinsip-prinsip korporasi yang sehat. Peraturan yang berlaku dalam hal ini berkaitan dengan misalnya masalah pajak, hubungan industrial, perlindungan lingkungan hidup, kesehatan/keselamatan kerja, standar penggajian, serta persaingan yang sehat. Dalam hal ini, PT Jamkrindo menerapkan mekanisme tata kelola perusahaan yang bersifat cross check untuk memastikan responsbilitas dari masing-masing fungsi struktur tata kelola perusahaan melaksanakan tugas dan tanggung jawabnya sebaik-baiknya tanpa benturan kepentingan dan intervensi. Artinya dalam hal ini PT. Jamkrindo selalu mendasarkan tata kelola perusahaannya berdasarkan peraturan yang berlaku.

\section{Kemandirian (Independency)}

Prinsip kemandirian yaitu keadaan di mana Perusahaan dikelola secara profesional tanpa benturan kepentingan dan pengaruh/tekanan dari pihak manapun yang tidak sesuai dengan peraturan perundang-undangan yang berlaku dan prinsip-prinsip korporasi yang sehat. Dalam mengimplementasikan hal ini, PT Jamkrindo dikelola secara profesional tanpa adanya benturan kepentingan ataupun intervensi dan dominasi dari pihak manapun.

\section{Kewajaran (Fairness)}

Prinsip kewajaran yaitu keadilan dan kesetaraan di dalam memenuhi hak- 
hak pemangku kepentingan yang timbul berdasarkan perjanjian dan peraturan perundang-undangan yang berlaku. Dalam kaitan dengan prinsip kewajaran, PT. Jamkrindo menerapkan kesetaraan kepada segenap pemangku kepentingan sesuai dengan peraturan dan perundangundangan yang berlaku.

\section{Keterbukaan Informasi PT Jamkrindo}

Dalam rangka transparansi kondisi keuangan dan non keuangan kepada stakeholders, setiap tahun PT. Jamkrindo menginformasikan laporan keuangan audited dan laporan tahunan di website Perusahaan yang beralamat di www.jamkrindo.co.id. Selain itu, di dalam website tersebut juga memuat profil Perusahaan, produk-produk yang dijaminkan dan informasi-informasi terkini yang berada dalam lingkungan Perusahaan. Selain itu, PT Jamkrindo juga menyediakan fasilitas berupa saluran pelaporan pengaduan pelanggaran atau penyimpangan yang terjadi di lingkungan Perusahaan melalui Whistleblowing System (WBS) yang dapat diakses melalui:
a) Website:
http://www.jamkrindo.co.id/ecg
b) Surat Tertulis: PO BOX 107123 JKP 10610
c) SMS dan Whatsapp: 08111717123
d) Email: wbs@iamkrindo.co.id

Selain soal laporan keuangan, PT Jamkrindo juga transparan dalam melaporkan berbagai unsur dalam pelaksanaan perusahaan. laporan tersebut biasanya dimuat dalam laporan penerapan tata kelola perusahaan yang baik sesuai dengan peraturan BUMN maupun Otoritas Jasa Keuangan (OJK). Misalnya pelaporan terkait pelaksanaan tugas dan tanggung jawab Direksi, Dewan Komisaris dan Dewan Pengawas Syariah. Selain itu, PT. Jamkrindo juga melakukan pelaporan tentang fungsi kepatuhan Auditor Internal dan Auditor Eksternal; penerapan manajemen risiko, sistem pengendalian internal dan tata kelola teknologi informasi; rencana panjang, rencana kerja dan anggaran tahunan; pelaporan tentang penerapan kebijakan remunerasi dan fasilitas lain bagi anggota direksi, dewan komisaris, DPS dan pegawai.

Kemudian juga pengungkapan kepemilikan saham anggota direksi dan dewan komisaris yang mencapai $5 \%$ (lima per seratus) atau lebih, yang meliputi jenis dan jumlah lembar saham; serta pengungkapan hubungan keuangan dan hubungan keluarga anggota direksi, anggota dewan komisaris, dan anggota DPS dengan anggota direksi lain, anggota dewan komisaris lain, anggota DPS lain, dan/atau pemegang saham lembaga penjamin tempat anggota direksi, anggota dewan komisaris dan anggota DPS dimaksud menjabat. ${ }^{1}$ Terkait transparnsi di PT Jamkrindo, berdasarkan surat Nomor: RC-821/PEFDIR/IX/2019 tanggal 09 September 2019 yang dikeluarkan oleh lembaga pemeringkat PEFINDO, PT. Jamkrindo mendapatkan peringkat $\mathrm{AA}+$ yaitu memiliki karakteristik keamanan keuangan yang sangat kuat relatif terhadap perusahaan lainnya di Indonesia, dengan hanya sedikit perbedaan dibandingkan peringkat yang lebih tinggi.

\section{Kepatuhan PT Jamkrindo terhadap Peraturan Perundang-undangan}

Seperti pada dasar pendirian PT. Jamkrindo berdasarkan beberapa aturan perundang-undangan serta peraturan Menteri dan lembaga yang berlaku. Beberapa aturan tersebut juga menjadi dasar dalam tata kelola dan mekanisme perusahan yang ada di dalamnya, sebagai berikut: 
1. Undang-Undang Nomor 19 Tahun 2003 tanggal 19 Juni 2003 tentang Badan Usaha Milik Negara.

2. Peraturan Pemerintah Nomor 41 tanggal 19 Mei 2008 tentang Perusahaan Umum Jaminan Kredit Indonesia (Perum Jamkrindo).

3. Peraturan Presiden Nomor 2 tanggal 26 Januari 2008 tentang Lembaga Penjaminan.

4. Peraturan Menteri Keuangan (PMK) Nomor: 99/PMK.010/2011 tanggal 8 Juli 2011 tentang dan Perubahan atas Peraturan Menteri Keuangan (PMK) Nomor: 222/PMK.010/2008 tanggal 16 Desember $2008 \quad$ tentang Perusahaan Penjaminan Kredit dan Perusahaan Penjaminan Ulang Kredit.

5. Keputusan Menteri Nomor: KEP77/KM. 10/2009 tanggal 22 April 2009 yang menetapkan izin usaha Perum Jamkrindo sebagai Perusahaan Penjaminan Kredit.

6. Undang-Undang Republik Indonesia Nomor 1 Tahun 2016 tentang Penjaminan.

7. Peraturan Otoritas Jasa Keuangan Nomor: 1/POJK.05/2017 tanggal 11 Januari 2017 tentang Perizinan Usaha dan Kelembagaan Lembaga Penjamin.

8. Peraturan Otoritas Jasa Keuangan Nomor: 2/POJK.05/2017 tanggal 11 Januari 2017 tentang Penyelenggaraan Usaha Lembaga Penjamin.

9. Peraturan Otoritas Jasa Keuangan Nomor: 3/POJK.05/2017 tanggal

11 Januari 2017 tentang Tata Kelola Perusahaan yang Baik Bagi Lembaga Penjamin.

10. Peraturan Otoritas Jasa Keuangan Nomor: 7/POJK.05/2014 tanggal 7 April 2014 tentang Pemeriksaan Lembaga Penjaminan.

Selain itu, hal lain juga dilaksanakan PT Jamkrindo berdasarkan kepatuhan terhadap aturan Perundang-undangan yang berlaku. Seperti mekanisme Pengangkatan dan tugas Dewan Pengawas dilakukan dengan Keputusan Menteri BUMN selaku RUPS/Pemilik Modal, sesuai dengan peraturan perundang-undangan, sebagai berikut:

1. Undang-undang Undang-Undang Nomor 19 Tahun 2003 tanggal 19 Juni 2003 tentang Badan Usaha Milik Negara;

2. Peraturan Pemerintah Nomor 45 Tahun 2005 Tentang Pendirian, Pengurusan, Pengawasan dan Pembubaran BUMN;

3. Peraturan Pemerintah Nomor 35 Tahun 2018 tentang Perusahaan Umum (Perum) Jaminan Kredit Indonesia;

4. Keputusan Menteri Negara Badan Usahan Milik Negara Nomor: PER-101/MBU/2002 Tentang Penyusunan Rencana Kerja dan Anggaran Perusahaan BUMN;

5. Peraturan Menteri Negara Badan Usaha Milik Negara Nomor: PER01/MBU/2011 dan perubahannya Nomor: $\quad$ PER-09/MBU/2012 tentang Penerapan Tata Kelola Perusahaan yang Baik pada Badan Usaha Milik Negara;

6. Peraturan Menteri Negara Badan Usaha Milik Negara Nomor: PER12/MBU/2011 tetang Organ Pendukung Dewan Komisaris/Dewan Pengawas Badan Usaha Milik Negara.

Kemudian, PT Jamkrindo juga melaksanakan tata kelola perusahaan yang baik atau Good Corporate Governance (GCG) pada Perusahaan yang didasari landasan hukum dan ketentuan peraturan yang berlaku, yaitu:

1. Undang-Undang Republik Indonesia Nomor 40 tahun 2007 tentang Perusahaan Terbatas;

2. Undang-Undang Republik Indonesia Nomor 19 tahun 2003 
tentang Badan Usaha Milik Negara (BUMN);

3. Undang-Undang Republik

Indonesia Nomor 14 Tahun 2008

Tentang Keterbukaan Informasi;

4. Peraturan Pemerintah Republik Indonesia Nomor 45 tahun 2001 tentang perubahan atas Peraturan Pemerintah Nomor 12 tahun 1998 tentang Perusahaan Perusahaan (Persero);

5. Peraturan Menteri Negara BUMN Nomor: $\quad$ PER-01/MBU/2011 tanggal 1 Agustus 2011 tentang Penerapan Tata Kelola Perusahaan yang Baik pada BUMN dan perubahannya Peraturan Menteri Negara BUMN Nomor: PER09/MBU/2012 tanggal 6 Juli 2012;

6. Keputusan Sekretaris Kementerian Badan Usaha Milik Negara Nomor: SK 16/S.MBU/2012 tanggal 6 Juni 2012 tentang Indikator/Parameter Penilaian dan Evaluasi atas Penerapan Tata Kelola Perusahaan yang Baik (Good Corporate Governance) pada BUMN.

Kemudian, PT Jamkrindo juga melakukan Penyusunan Rencana Kerja dan Anggaran Perusahaan (RKAP) PT Jaminan Kredit Indonesia Tahun mengacu pada:

1) Undang - undang Nomor 19 tahun 2003 tentang Badan Usaha Milik Negara (BUMN) junto Peraturan Pemerintah Nomor 45 tahun 2005 tentang Pendirian, Pengurusan, Pengawasan dan Pembubaran Badan Usaha Milik Negara.

2) Keputusan Menteri BUMN Nomor: $\quad$ KEP-101/MBU/2002 tanggal 4 Juni 2002 tentang Penyusunan Rencana Kerja dan Anggaran Perusahaan Badan Usaha Milik Negara (BUMN);

3) Surat Edaran Direksi Nomor: 3681/P/1/IX/2019 tanggal 2 September 2019 tentang penyusunan RKAP Tahun Buku 2020;

4) Surat Menteri BUMN Nomor: S574/MBU/08/2019 tanggal 30 Agustus 2019 tentang Aspirasi Pemegang Saham/Pemilik Modal untuk Penyusunan Rencana Kerja dan Anggaran Perusahaan Tahun 2020 .

\section{Penilaian Terhadap Pelaksanaan Tata Kelola Perusahaan yang Baik di PT Jamkrindo}

PT Jamkrindo dalam menjalankan bisnis penjaminan kredit/pembiayaan kepada UMKMK senantiasa dituntut untuk memanfaatkan peluang usaha secara baik dan menguntungkan dengan tetap memperhatikan unsur-unsur amanah, transparansi dan akuntabilitas. Agar penerapan praktik Tata Kelola Perusahaan yang Baik (Good Corporate Governance) berjalan secara baik dan memberikan hasil yang bernilai tinggi maka harus berlandaskan pada nilai moral, kepatuhan terhadap peraturan/perundangan, serta kesadaran akan tanggung jawab sosial Perusahaan terhadap stakeholder.

Pada tahun 2017, Otoritas Jasa Keuangan (OJK) menerbitkan Peraturan Otoritas Jasa Keuangan Nomor: 03/POJK.05/2017 tanggal 11 Januari 2017 tentang Tata Kelola Perusahaan yang baik bagi Lembaga Penjamin dan Surat Edaran Otoritas Jasa Keuangan Nomor: 54/SEOJK.05/2017 tanggal 12 Oktober 2017 tentang Laporan Penerapan Tata Kelola Perusahaan yang Baik Bagi Lembaga Penjamin, sehingga Perusahaan wajib melakukan Self Assessment setiap tahun yang mengacu pada peraturan tersebut. Melalui pelaporan tersebut kemudian PT Jamkrindo selalu mendapat predikat yang memuaskan terkait penerapan Good Corporate Governance di perusahaan penjaminan tersebut. 
Misalnya pada tahun 2018, PT Jamkrindo memperoleh skor capaian sebesar 91,68 dari skor maksimal 100 atau 91,68\%. Kemudian pada tahun 2019 hasil self assessment PT Jamkrindo memperoleh skor capaian sebesar 92,47. Dengan nilai tinggi seperti itu, PT Jamkrindo memperoleh predikat "Sangat Baik"

Selain laporan berdasarkan peraturan OJK, PT Jamkrindo juga melakukan Independent Assessment atas implementasi Good Corporate Governance yang dilaksanakan dengan menggunakan kriteria Faktor Uji Kesesuaian (FUK) yang ditetapkan berdasarkan Keputusan Sekretaris Menteri BUMN Nomor: SK16/S.MBU/2012 tentang

Indikator/Parameter Penilaian dan Evaluasi atas Penerapan Tata Kelola Perusahaan Yang Baik (GCG) pada BUMN. Faktor Uji Kesesuaian tersebut dikelompokkan pada 6 (enam) aspek pokok, yaitu: Komitmen Terhadap Penerapan Tata Kelola Perusahaan yang Baik Secara Berkelanjutan; Pemegang Saham dan RUPS/Pemilik Modal; Dewan Komisaris/Dewan Pengawas; Direksi; Pengungkapan Informasi dan Transparansi; Aspek Lain.

Berdasarkan dari 6 aspek tersebut, PT Jamkrindo juga mendapat nilai yang memuaskan. Misalnya dalam laporan tahun 2018, terkait Komitmen Terhadap Penerapan Tata Kelola Perusahaan yang Baik Secara Berkelanjutan, skor hasil asesmen pada aspek ini mencapai 6,924 atau 98,913\% dari bobot keseluruhan sebesar 7,000; Pemegang Saham dan RUPS/Pemilik Modal, skor hasil asesmen pada aspek ini mencapai 8,957 atau 99,519\% dari bobot keseluruhan sebesar 9,000; Dewan Komisaris/Dewan Pengawas, skor hasil asesmen pada aspek ini mencapai 33,351 atau 95,289\% dari bobot keseluruhan sebesar 35,000; Direksi, skor hasil asesmen pada aspek ini mencapai 33,355 atau 95,301\% dari bobot keseluruhan sebesar 35,000; Pengungkapan Informasi dan Transparansi skor hasil asesmen pada aspek ini mencapai 8,754 atau 97,267\% dari bobot keseluruhan sebesar 9,000; Aspek Lain, skor hasil asesmen pada aspek ini mencapai 4,375 atau 87,500\% dari bobot keseluruhan sebesar 5,000.

\section{KESIMPULAN DAN SARAN}

\section{Kesimpulan}

Penerapan Good $\begin{array}{r}\text { Corporate } \\ \text { Governance (GCG) atau tata }\end{array}$
kelola perusahaan yang baik di PT
Jamkrindo didasarkan pada
prinsip-prinsip yang berlaku di
dalam aturan Perundang-undang.
Pada pemaparan di bab-bab
sebelumnya dijelaskan bahwa PT
Jamkrindo melaksanakan GCG
didasarkan pada Undang-Undang
Nomor 40 Tahun 2007 tentang
Perseroan Terbatas (UU PT), yang
meliputi beberapa prinsip tersebut
di antaranya Prinsip Keterbukaan
(transparancy), prinsip
akuntabilitas (accountability),
Prinsip tanggungjawab
(responsibility), prinsip
kemandirian (independency) dan prinsip kewajaran atau kesetaraan (fairness) yang sesuai dengan teori corporate governance yang mengatur pola hubungan harmonis antara organ perseroan, (Rapat umum pemegang saham, direksi dan dewan komisaris) dan pemangku kepentingan lainnya (stakeholder).

Selain UUPT, PT Jamkrindo juga mengacu pada beberapa peraturan seperti Undang-Undang Republik Indonesia Nomor 19 tahun 2003 tentang Badan Usaha Milik Negara (BUMN); Undang-Undang Republik Indonesia Nomor 14 Tahun 2008 Tentang Keterbukaan 
Informasi; Peraturan Pemerintah Republik Indonesia Nomor 45 tahun 2001 tentang perubahan atas Peraturan Pemerintah Nomor 12 tahun 1998 tentang Perusahaan Perusahaan (Persero); Peraturan Menteri Negara BUMN Nomor: PER-01/MBU/2011 tanggal 1 Agustus 2011 tentang Penerapan Tata Kelola Perusahaan yang Baik pada BUMN dan perubahannya Peraturan Menteri Negara BUMN Nomor: $\quad$ PER-09/MBU/2012 tanggal 6 Juli 2012; Keputusan Sekretaris Kementerian Badan Usaha Milik Negara Nomor: SK 16/S.MBU/2012 tanggal 6 Juni 2012 tentang Indikator/Parameter Penilaian dan Evaluasi atas Penerapan Tata Kelola Perusahaan yang Baik (Good Corporate Governance) pada BUMN.

PT Jamkrindo juga berkomitmen dalam upaya menerapkan prinsipprinsip GCG dengan diwujudkannya Pedoman Tata Kelola yang diterapkan secara konsisten sehingga semua nilai yang dimiliki oleh pihak-pihak yang berkepentingan atas perusahaan dapat digunakan secara optimal dan menghasilkan pola hubungan ekonomis yang saling menguntungkan. Penerapan prinsip-prinsip GCG bukan hanya untuk memenuhi peraturan perundang-undangan. PT. Jamkrindo memiliki komitmen yang kuat, bahwa penerapan GCG harus berlandaskan pada standar etika tertinggi yang menjadi salah satu fondasi bagi pertumbuhan usaha Perusahaan yang berkelanjutan. Dalam menerapkan prinsip-prinsip GCG, PT Jamkrindo menekankan prinsip keterbukaan informasi atau transparansi melalui informasi laporan keuangan audited dan laporan tahunan di website Perusahaan yang beralamat di www.jamkrindo.co.id. Kemudian, PT Jamkrindo juga melaksanakan kejelasan tugas-tugas Direksi, Dewan Pengawas, dan Dewan Pengawas Syariah dalam rangka melaksanakan prinsip akuntabilitas. Termasuk pembagian tugas Dewan Pengawas. Kemudian juga menerapkan fungsi Auditor Internal dan Eksternal. Selain itu, dalam rangka menerapkan independensi, Dewan Pengawas, Direksi dan seluruh Karyawan Perum Jamkrindo berkomitmen untuk tidak menerima dan/atau meminta hadiah, bingkisan atau gratifikasi dalam bentuk apapun baik secara langsung maupun tidak langsung dari seluruh pemangku kepentingan (stakeholder) dan pihak-pihak lain yang berhubungan dengan PT Jamkrindo. Dalam hal ini PT. Jamkrindo menerapkan Sistem Manajemen Anti Penyuapan (SMAP). Dalam setiap pelaksanaan tata kelola perusahaan, PT Jamkrindo selalu menaati mekanisme perundangundangan yang berlaku. Hal ini memenuhi prinsip GCG yakni pertanggungjawaban seperti mekanisme Pengangkatan dan tugas Dewan Pengawas didasarkan pada beberapa aturan Undangundang, pelaksanaan tata kelola perusahaan yang baik atau Good Corporate Governance (GCG), juga terkait Penyusunan Rencana Kerja dan Anggaran Perusahaan (RKAP). Berdasarkan pemaparan tersebut PT Jamkrindo telah melakukan beberapa upaya dalam rangka menerapkan Tata Kelola Perusahaan yang baik. Hal ini terbukti dari laporan-laporan self asessement yang dibuat oleh PT 
Jamkrindo kepada Otoritas Jasa Keungan dan Kementerian Badan Usaha Milik Negara (BUMN) terkait pelaksanaan GCG selalu mendapatkan nilai memuaskan dengan predikat "sangat baik".

\section{Saran}

1. Bagi PT Jamkrindo diharapkan terus meningkatkan peranan dari prinsip-prinsip Good Corporate Governance. Hal tersebut dikarenakan penting dan sangat bermanfaat untuk meningkatkan kinerja dan nilai perusahaan.

2. Bagi peneliti selanjutnya:

a Variabel penelitian yang digunakan dalam penelitian selanjutnya dapat diperluas antara lain menggunakan proksi Good Corporate Governance yang lebih bervariasi dan proksi kinerja perusahaan yang lebih banyak. Hasil penelitian yang baru dapat dibandingkan dengan penelitian yang telah ada dan dapat memberikan perbandingan yang lebih relevan dengan teori yang ada.

b. Sampel penelitian dapat diperluas dan didasarkan pada jenis industrinya agar dapat mengkaji atau menganalisis pengaruh Good Corporate Governance terhadap tiap-tiap industri karena masing-masing industri memiliki kinerja operasional yang berbeda, sehingga penilaiannya pun seharusnya bervariasi.

c. Penelitian selanjutnya dapat memperluas jangkauan informasi yang dikumpulkan agar tidak terbatas pada laporan tahunan dan laporan keuangan. 


\section{DAFTAR PUSTAKA}

Jamkrindo, P. (2018). Lapora Penilaian Penerapan Tata Kelola Perusahaan Berdasarkan Metode SK-16 untuk Perum Jamkrindo. Indonesian Institute for Corporate Directorship.

Jamkrindo, P. (2019). Laporan Penilaian atas Penerapan Tata Kelola Perusahaan yang Baik (Good Corporate Governance), Self Assessment (Sesuai dengan Peraturan OJK).

Santo, B. S. (2019, Juli 13). Performa Bisnis Meningkat, Perum Jamkrindo Tak Melupakan UMKM. Available online:

https://m.suarakarya.id/detail/95925/ Performa-Bisnis-Meningkat-PerumJamkrindo-Tak-Melupakan-UMKM Retrieved: (tanggal akses)

Satriani, W. (2016, Mei 26). Pefindo ganjar Jamkrindo peringkat AA. Available online: https://keuangan.kontan.co.id/news/p efindo-ganjar-jamkrindo-peringkataa Retrieved: (tanggal akses)

Undang-Undang Republik Indonesia tentang Perseroan Terbatas, UU No.40, (Lembaran Negara Republik Indonesia Tahun. 2007Nomor 106, Tambahan Lembaran Negara Republik Indonesia Nomor 4756). (n.d.).

Keputusan Menteri Negara Badan

Usaha Milik Negara Nomor:

PER- 101/MBU/2002 Tentang
Penyusunan Rencana Kerja dan Anggaran Perusahaan BUMN.

Keputusan Menteri Nomor: KEP77/KM. 10/2009 tanggal 22 April 2009 yang menetapkan izin usaha Perum Jamkrindo sebagai Perusahaan Penjaminan Kredit.

Keputusan Sekretaris

Kementerian Badan Usaha Milik Negara Nomor: SK 16/S.MBU/2012 tanggal 6 Juni 2012 tentang Indikator/Parameter Penilaian dan Evaluasi atas Penerapan Tata Kelola Perusahaan yang Baik (Good Corporate Governance) pada BUMN. Anggaran Perusahaan Badan Usaha Milik Negara (BUMN)

Peraturan Menteri Negara Badan Usaha Milik Negara Nomor: PER-01/MBU/2011 dan perubahannya Nomor: PER09/MBU/2012 tentang Penerapan Tata Kelola Perusahaan yang Baik pada Badan Usaha Milik Negara.

Peraturan Presiden Nomor 2 tanggal 26 Januari 2008 tentang Lembaga Penjaminan.

Peraturan Pemerintah Nomor 41 tanggal 19 Mei 2008 tentang Perusahaan Umum Jaminan Kredit Indonesia (Perum Jamkrindo). 
Peraturan Menteri Negara Badan Usaha Milik Negara Nomor: PER12/MBU/2011 tetang Organ Pendukung Dewan Komisaris/Dewan Pengawas Badan Usaha Milik Negara.

Peraturan Menteri Keuangan (PMK) Nomor: 99/PMK.010/2011 tanggal 8 Juli 2011 tentang dan Perubahan atas Peraturan Menteri Keuangan (PMK) Nomor: 222/PMK.010/2008 tanggal 16 Desember 2008 tentang Perusahaan Penjaminan Kredit dan Perusahaan Penjaminan Ulang Kredit.

Peraturan Menteri Negara BUMN Nomor: PER-01/MBU/2011 tanggal 1 Agustus 2011 tentang Penerapan Tata Kelola Perusahaan yang Baik pada BUMN dan perubahannya Peraturan Menteri Negara BUMN Nomor: PER09/MBU/2012 tanggal 6 Juli 2012;

Peraturan Otoritas Jasa Keuangan Nomor: /POJK.05/2017 tanggal 11 Januari 2017 tentang Perizinan Usaha dan Kelembagaan Lembaga Penjamin.

Peraturan Otoritas Jasa Keuangan Nomor: 2/POJK.05/2017 tanggal 11 Januari 2017 tentang Penyelenggaraan Usaha Lembaga Penjamin.

Peraturan Otoritas Jasa Keuangan Nomor:

3/POJK.05/2017 tanggal 11 Januari 2017 tentang Tata Kelola Perusahaan yang Baik Bagi Lembaga Penjamin.
Peraturan Otoritas Jasa Keuangan Nomor: 7/POJK.05/2014 tanggal 7 April 2014 tentang Pemeriksaan Undangundang Undang-Undang Nomor 19 Tahun 2003 tanggal 19 Juni 2003 tentang Badan Usaha Milik Negara.

Peraturan Pemerintah Republik Indonesia Nomor 45 tahun 2001 tentang perubahan atas Peraturan Pemerintah Nomor 12 tahun 1998 tentang Perusahaan Perusahaan (Persero). 
Peraturan Pemerintah

Nomor 45 Tahun

2005 Tentang Pendirian,

Pengurusan, Pengawasan

dan Pembubaran BUMN.

Peraturan Pemerintah Nomor

35 Tahun 2018

tentang Perusahaan

Umum (Perum) Jaminan

Kredit Indonesia.

Surat Edaran Direksi

No. 3681/P/1/IX/2019

tanggal 2 September

2019 tentang

penyusunan RKAP

Tahun Buku 2020.

Surat Menteri

BUMN Nomor: S574/MBU/08/2019

tanggal 30 Agustus 2019

tentang Aspirasi Pemegang

Saham/Pemilik Modal

untuk Penyusunan Rencana

Kerja dan Anggaran

Perusahaan Tahun 2020.

Undang-Undang

Nomor 19 Tahun 2003

tanggal 19 Juni 2003.

tentang Badan Usaha

Milik Negara.

Undang-Undang Republik

Indonesia Nomor 19 tahun

2003 tentang Badan Usaha Milik

Negara (BUMN).
Undang-Undang Republik

Indonesia Nomor 14 Tahun 2008

Tentang Keterbukaan Informasi.

Undang-Undang

Republik Indonesia No.

40 tahun 2007 tentang

Perusahaan Terbatas.

Undang-Undang Republik

Indonesia Nomor 1 Tahun

2016 tentang Penjaminan. 